\title{
The Performance of High-Growers and Regional Entrepreneurial Ecosystems: A Research Framework
}

\author{
Marta Gancarczyk
}

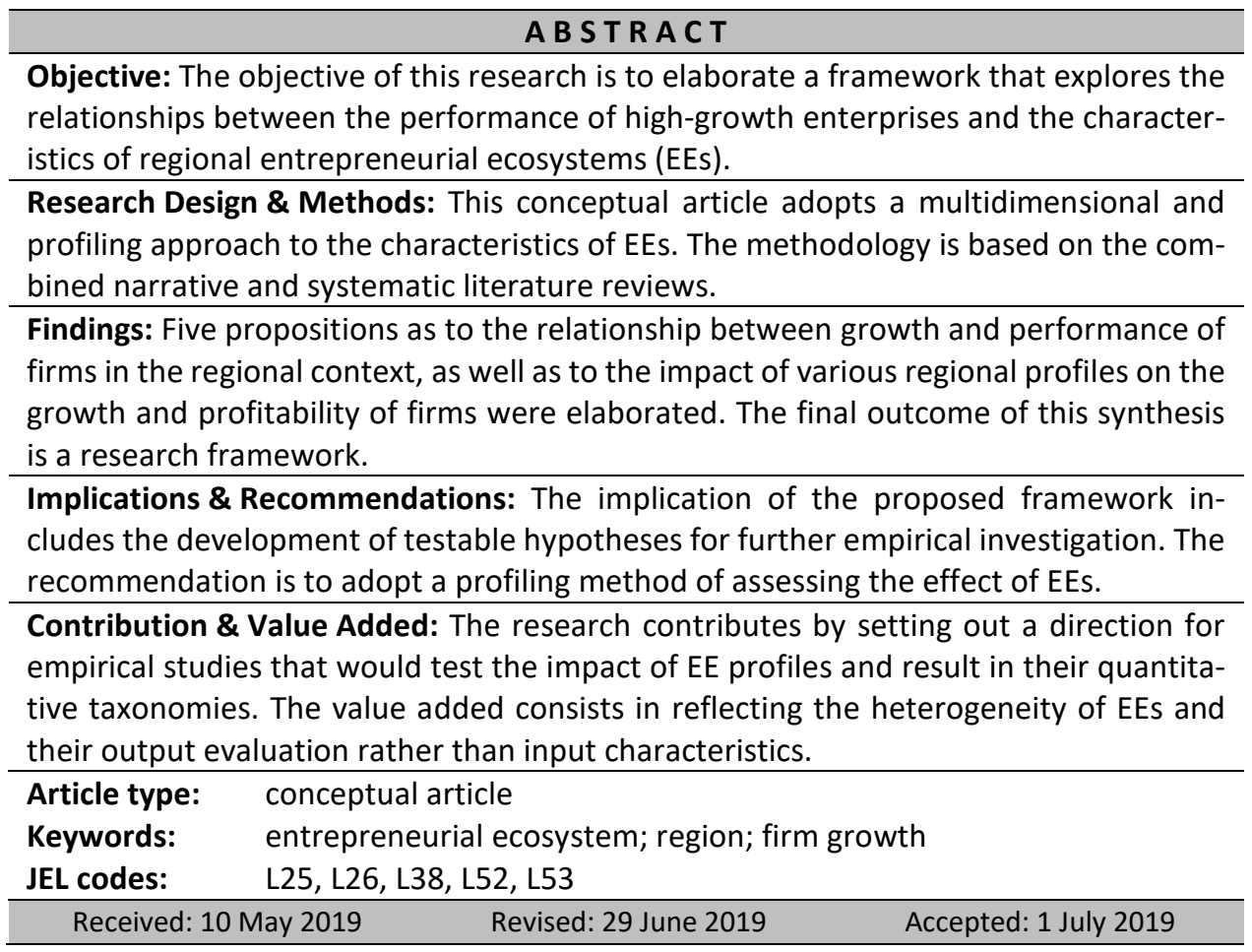

\section{Suggested citation:}

Gancarczyk, M. (2019). The Performance of High-Growers and Regional Entrepreneurial Ecosystems: A Research Framework. Entrepreneurial Business and Economics Review, 7(3), 99-123. https://doi.org/10.15678/EBER.2019.070306 


\section{INTRODUCTION}

There is rich evidence of the economic contribution of high-growth firms toemployment, value-added, and innovation (Birch, Haggerty, \& Parsons, 1995; Coad, 2009; Stam et al., 2006; Acs, Parsons, \& Tracy, 2008; OECD, 2007; 2010; Wach, 2012). This input is one of the rationales for the on-going shift in industrial and entrepreneurship policies, from the focus on start-ups and general entrepreneurial activity to performance and productive entrepreneurship, i.e. quality ventures that turn to scale-ups, high-growers or unicorns (Baumol, 1996; Mason \& Brown, 2014; Isenberg \& Brown, 2014; Acs et al., 2017; Stam, 2015; 2017).

Within the extensive research on high-growth enterprises, the importance of performance as profitability vs growth as size increase is rarely investigated (Davidsson, Steffen, \& Fitzsimmons, 2009; Steffen, Davidsson, \& Fitzsimmons, 2009; Zbierowski, 2012). Nevertheless, both theory and practice point to the difference between growth as size increase and performance as economic efficiency (Brown \& Mawson, 2016; Brown, Mawson, \& Mason, 2017; Achtenhagen, Naldi, \& Melin, 2010; Bolek, 2018; Marris, 1964). Expansion is measured by revenue, employment, asset value or value-added dynamics, and performance denotes economic efficiency, measured by profitability dynamics (Brown et al., 2017; Achtenhagen, Naldi, \& Melin, 2010; Nicholls-Nixon, 2005; Marris, 1964). Moreover, growth is rather a means to increase economic efficiency than the ultimate objective of enterprises (Achtenhagen, Naldi, \& Melin, 2010). Moreover, profitability is conducive both for survival and sustainable growth (Davidsson, Steffen, \& Fitzsimmons, 2009; Mogos, Davis, \& Baptista, 2015). Beside firm- and entrepreneur-specific characteristics, it is recognized that environmental conditions affect growth and performance of firms (Brown, Mawson, \& Mason, 2017; Capozza, Salomone, \& Somma, 2018; Wiklund, Patzelt, \& Shepherd, 2009). However, the environmental factors are under-researched causes of firm expansion relative to capability factors (Brown \& Mason, 2017; Welter, 2011; Zahra \& Wright, 2011).

Recently, the role of contextual, environmental conditions has gained importance in the entrepreneurship research focused on venture creation and expansion (Chandler, McKelvie, \& Davidsson, 2009; Wach, 2008; Lisowska, 2012; Welter, 2011; Zahra \& Wright, 2011). This context is often presented as entrepreneurial ecosystems (EEs) that involve interrelations among industrial, social, and institutional conditions in specific territorial units (Mason \& Brown, 2014; Isenberg, 2010). The idea of EEs emerged as a response to the shift in economic policy toward productive entrepreneurship and from its inception it has been centred around firm growth (Stam \& Spigel, 2016; Mason \& Brown, 2014; Stam, 2017; Acs et al., 2017). The major research and policy problem of the EE literature is how EEs can enhance the growth and performance of firms.

Considering the interrelated fields of firm growth and EEs, research on the impact of EEs on firms' expansion is scarce (Acs et al., 2017; e.g., Auerswald \& Dani, 2017; Thomas, Sharapov, \& Autio, 2018). Particularly, there is a gap in investigating EEs' impact on profitable and thus sustainable growth. Consequently, the objective of this article is to develop a research framework that explores the relationships between the performance of highgrowth enterprises and the characteristics of regional entrepreneurial ecosystems.

The article is conceptual in nature and adopts the method of combined narrative and systematic literature reviews, as justified by the underexplored research on the growth- 
profitability nexus and by the initial stage of EE studies. Moreover, integrating these two streams into one research problem is also in the inception phase of investigation.

Our article addresses research gaps, i) in the area of the role of entrepreneurial ecosystems in the performance of high-growers, ii) in the area of interdependencies between growth and performance of enterprises. Consequently, this study intends to provide three contributions. First, it advances the literature on entrepreneurial ecosystems, by proposing how different profiles of EEs contribute to firms' growth and performance. Second, it adds to the studies on entrepreneurial growth, by proposing how the performance of highgrowers is conditioned by the context. Third, it enables knowledge accumulation by proposing the research framework that integrates firm growth and EE studies.

After the introduction, in the Material and Methods section, we present a methodological background of the study. The Literature Review and Theory Development section proposes a research framework for studying the impact of EE characteristics on the performance of high-growers. The Discussion section synthesizes the research in relation to extant literature, as well as explains its contribution. Conclusions, limitations, and implications for further investigations, entrepreneurial practice, and policy follow in the last section.

\section{MATERIAL AND METHODS}

The article combines two interrelated research streams, namely, (1) studies on firm growth and (2) studies on the entrepreneurial ecosystems, thus seeking knowledge accumulation and advancements in the both streams. This approach is justified by the interrelated research gaps that are present in those streams, and that can be resolved by the formulation of the integrative problem. We adopt a conceptual approach, with the use of narrative literature review as a major method and systematic literature review as a complementary method. Both methods are subordinated to the expected outcome of developing a research framework.

Therefore, the research procedure involved two major phases.

(i) Narrative literature review.

Narrative literature review is justified by the breadth and early development stages of the fields under study (Collins \& Fauser, 2005). The two research fields of growth-profitability nexus and EEs are initial and underexplored, while their combination makes the search broad. As an outcome, narrative reviews are expected to identify specific research questions or propositions (Green, Johnson, \& Adams, 2006). Relative to systematic literature review, this type of research involves a subjective component. However, the selection procedure and choices need to be explained (Green, Johnson, \& Adams, 2006).

The search was performed predominantly in the databases of Web of Science, Scopus, and Proquest, as well as monographs filtered through Google Books. We screened primarily peer reviewed leading journals on entrepreneurship and regional development, indexed in Web of Science and/or Scopus. The focus was on the theoretical and empirical papers in the area of:

- firm growth, particularly the performance of high-growers and the role of regional environment in this regard,

- entrepreneurial ecosystems, particularly their essence and impact on the growth and performance of firms. 
The final sample counted more than 70 academic peer-reviewed papers and monographs.

The outcomes of the narrative literature review were as follows:

- the identification of the major gaps in the two interrelated fields of firm growth and EEs and the formulation of the major, integrated research problem,

- the acknowledgement of the drawbacks of extant methodological approaches to the quantitative evaluation of the EE impact,

- the choice of a profiling approach to synthesize the findings from the literature reviewed and to guide the final framework.

Extant conceptual approaches to EES have identified sets of actors and factors that combine to generate productive entrepreneurship. However, little is known about the governance mechanisms, i.e. how relationships among EE components are coordinated (Stam \& Spigel, 2016; Brown \& Mason, 2017; Stam, 2017; Colombo et al., 2019; Audretsch \& Link, 2019; Colombelli \& Paolucci, 2019). This prevents reflecting the systemic nature of EEs (Brown \& Mason, 2017). In order to address this deficiency, we adopted extant models of governance and innovation that put stress on causal relationships among systemic components (Acs et al., 2017; Brown \& Mason, 2017).

Moreover, extant methodologies focus on input characteristics of EEs, such as institutional density, venture capital activity or patents (GC, 2018; Stangler \& Ben-Masterson, 2015). Although the attention to outputs is recommended, the evidence of EE outcomes in terms of the performance of growth firms and scale-ups remains limited (Acs et al., 2017; Stam, 2017; Nicotra et al., 2018). In response to this gap, we evaluate the effect of EEs on the growth and performance of regional enterprises.

Although the case-based empirical evidence on EEs is developing (e.g., Auerswald \& Dani, 2017; Cunningham, Menter, \& Wirsching, 2019; Thomas, Sharapov, \& Autio, 2018), quantitative studies are still scarce and largely unsuccessful in confirming the impact of EEs on the performance of regions and firms (Bruns et al., 2017; Acs et al., 2017). The cause might be unique characteristics of each territory (Acs et al., 2017; Mason \& Brown, 2013; Martin \& Sunley, 2003), while extant methodologies tested sets of factors expected to bring similar effects in heterogeneous locations. Following the recommendation by Acs et al. (2017) as well as Brown \& Mason (2017), we adopted extant models of regional governance as canvas to identify various profiles of regional EEs (Markusen, 1996; Sturgeon, 2003; Guerrieri \& Pietrobelli, 2004; Simsek, Heavey, \& Fox, 2017; Law et al., 1998). The models were revisited and evaluated based on the advancements in the regional development literature. To synthesize these advancements, the systematic literature review was performed in the next step of the research.

(ii) Systematic literature review in the area of the impact of regional environment on firms' growth and profitability.

The systematic review was to explore a more strictly defined topic that emerged as a result of the narrative literature review (Green, Johnson, \& Adams, 2006). The review was focused on the impact of regional environment on firms' growth and profitability.

The investigation was performed in the Scopus and Web of Science databases. The search phrase combined the key words of "firm*/compan*y growth" or "high grow*th" and region* or "region* al environment," to be found in titles, abstracts, or key words. The Scopus database produced more than 2500 and Web of Science more than 600 results in the 
first phase. However, after limiting the investigation to the fields of economics, business, social science and economic geography, Scopus revealed 276 results. The focus was on the English language articles published starting from 2000, to reflect the knowledge development after the considered models of regional innovation and governance were published (Markusen, 1996; Sturgeon, 2003; Guerrieri \& Pietrobelli, 2004). Another criterion was the journal's interest and competence in the field, confirmed by at least four publications within the topics under research for Scopus and two publications for Web of Science, due to the latter being more selective. The next step included screening the abstracts according to the paper's relevance for the research, which resulted in 43 articles combined from both databases. The limited number of relevant papers reflects an underexplored nature of the area under study. Considering this nature, we followed the recommendation by Hoon (2013) to perform an additional manual search. The investigation was exercised in the area of industrial district and regional cluster literature to expand the evidence by 32 papers. The literature in this area is considered particularly relevant for understanding the development of productive entrepreneurship in the region (Isenberg, 2010; Brown \& Mason, 2017).

When reviewing the final sample of papers, we particularly focused on the characteristics of regional environments that had an effect on the growth and performance of firms. These characteristics were grouped according to the structural elements derived from the regional governance and innovation models (Markusen, 1996; Sturgeon, 2003; Guerrieri \& Pietrobelli, 2004).

\section{LITERATURE REVIEW AND THEORY DEVELOPMENT}

\section{The Growth-Performance Relationship in the Regional Context}

There is an increasing recognition that the economic importance of entrepreneurial activity depends on quality enterprises or productive entrepreneurship (Baumol, 1996; Birch et al., 1995; Coad, 2009; Stam et al., 2006; Acs et al., 2008; OECD, 2007; 2010). These are high growth-oriented firms that innovate based on the investment in R\&D, and expand into new products, processes, and markets applying technological advancements (OECD, 2010). The contribution of high-growers to employment, value-added and innovation is disproportionally large relative to their small representation in the population of enterprises (Birch et al., 1995; Coad, 2009; Stam et al., 2006; Acs et al., 2008). The remaining, predominant population expands only incrementally or does not grow at all, maintaining a stable base for the economy, however, with a limited contribution to its dynamics (Coad, 2009). The firm's highgrowth is predominantly defined as considerable size increase within a short time, which is associated with qualitative upgrading of capabilities (Penrose, 1959; Moreno \& Casillas, 2007). It is often assumed that rapid expansion features at least doubling the initial size, as measured by sales, employment, asset value or value-added, within 3-5 years (Moreno \& Casillas, 2007; Birch et al., 1995; Smallbone et al., 1995; Acs, Parsons, \& Tracy, 2008; OECD, 2007; 2010). The investigation of performance is the more compelling that high growth involves risk and even uncertainty, due to considerable investment in technological innovations and new markets (OECD, 2010). Such an intensive investment is challenged by uncertainty, as well as low levels of liquidity and solvency, which raises concerns regarding the growth-performance relationship (Oliveira \& Fortunato, 2006). 
The extant studies on firm growth determinants are largely inconclusive as to the consistent set of growth and profitability determinants (Shepherd \& Wiklund, 2009). These studies are predominantly focused on the resource-based factors, such as entrepreneurs' and firms' characteristics, with limited attention to the impact of environmental context (Chandler, McKelvie, \& Davidsson, 2009; Brown \& Mason, 2017). However, the environmental influences are increasingly recognized as considerable explanatory factors of entrepreneurial choices (Brown \& Mason, 2017; Welter, 2011; Welter, Baker, \& Wirsching, 2019; Zahra \& Wright, 2011; Lipińska, 2018). They are also promising in resolving the ambiguity of findings as to expansion determinants (Chandler, McKelvie, \& Davidsson, 2009; Brown \& Mason, 2017).

The few studies that explore the relationships between growth and profitability focus on such characteristics of firms pursuing growth as age and earlier growth and profitability (Wiklund, 1999; Garnsey et al., 2006; Steffens et al., 2009; Glancey, 1998; Bolek, 2018). Earlier growth affects future prospects of growth and profitability (Wiklund, 1999; Garnsey et al., 2006; Steffens et al., 2009; Botazzi \& Secchi, 2006; Coad, 2009). Growth is cumulative and self-reinforcing, i.e., prior expansion produces growth and efficiency due to dynamic increasing returns to growth (economies of scale, scope, network, and experience) (Botazzi \& Secchi, 2006; Coad, 2009). However, it was also found that profitable low-growers are more likely to accomplish both future high growth and high profitability (Garnsey et al., 2006; Davidsson, Steffen, \& Fitzsimmons, 2009). Compared to high-growth but lowprofitability firms, profitable low-growers are also less exposed to the threat of future low growth and low performance (Davidsson, Steffen, \& Fitzsimmons, 2009). Other studies indicate a trade-off between growth and profitability due to time compression diseconomies, when the faster the expansion, the higher the expansion cost, and due to several management problems (Davidsson et al., 2008; Dierickx \& Cool, 1989; Steffens et al., 2009; Markman \& Gartner, 2002; Hambrick \& Crozier, 1985; Nicholls-Nixon, 2005). The above research evidences the relationship between growth and profitability dynamics, however, it remains inconclusive whether the nature of this relationship as positive or negative, and regarding what moderates this relationship.

The unexplained variance in growth and venture creation determinants attracted the attention to the role of differing entrepreneurial contexts, including regional environments (Brown et al., 2014; Capozza et al., 2018; Chandler et al., 2009; Welter, 2011; Zahra \& Wright, 2011). This view resonates with the earlier growth-of-the-fitter assumption stating that expansion is accomplished by those who best adapt to and most efficiently exploit the environment (Nelson \& Winter, 1982; Alchian, 1950; Downie, 1958; Aldrich, 1999, Dosi \& Grazzi, 2006; David, 2006). The importance of environmental niches is emphasized, where necessary resources can be exploited (Hannan \& Freeman, 1977; Hannan, 2005; Geroski, 2001).

Consequently, firms featuring the same regional context might experience similar growth and profitability patterns (Brown et al., 2014; Capozza et al., 2018; Dosi \& Grazzi, 2006; Chandler, McKelvie, \& Davidsson, 2009; Coad, 2009; Lumpkin \& Dess, 1996). The extant findings prove the importance of favourable context conditions (resource munificence, financial and institutional support) for firm growth and profitability (Bruns et al., 2017; Barbosa \& Eiriz, 2011). Environments differ in resource munificence and can support growth and profitability by the access to financing (Wiklund, 1999; Wiklund \& Shepherd, 2003; 
Chandler et al., 2009; Gagliardi, 2009; Colombo \& Grilli, 2005) and institutional support (Janssen, 2009; Baughn et al., 2010; Corrente et al., 2019). Moreover, territorial units feature different levels of GDP, market, and innovation dynamics that affects firms' growth and performance (Wiklund \& Shepherd, 2003; Coad, 2009; Kangasharju, 2000; Lumpkin \& Dess, 1996; Corrente et al. 2019). Based on the evidence that various regional environments differently affect the growth and performance of firms, we formulate the first proposition.

Proposition 1: The relationship between growth and profitability of enterprises is moderated by the regional context.

\section{The Characteristics of Regional EEs and the Performance of High-Growers}

The EE concept recognizes the importance of territorial environments for productive entrepreneurship that is best reflected in high-growers and scale-ups or unicorns (Mason \& Brown, 2014; Brown \& Mason, 2017; Stam, 2017; Spigel, 2016; Dominiak, Wasilczuk, \& Starnawska, 2016). The EE concept focuses on the performance of firms and territorial units, especially local and regional settings, however, countries and world regions are also considered (Bruns et al., 2017). It emerged as a policy measure to support quality startups and firm growth rather than entrepreneurship at large. As such, EEs are one of the markers of the new industrial policy that acknowledges an uneven contribution of entrepreneurial activity and focuses on the enterprises that provide the largest and most sustainable outcomes in terms of employment and value added (Brown \& Mason, 2017).

Entrepreneurial ecosystems are presented as sets of interrelated actors and factors that generate productive entrepreneurship in specific territorial units (Stam, 2017; Stam \& Spigel, 2016). Although broad, this definition captures the core of EEs as focused on the performance of firms and regions within spatial, geographical boundaries (Mason \& Brown, 2014; Brown \& Mason, 2017; Acs et al., 2017). Other definitions are more focused on the components of EEs, emphasizing types of actors, factors and dimensions that constitute this phenomenon (Mason \& Brown, 2014; Brown \& Mason, 2017; Spigel, 2017; Nicotra et al., 2018). The composition of actors and factors is unique to the location considered, however, the frameworks of EEs propose some most relevant and universal components (Brown \& Mason, 2017). The actors may include ambitious entrepreneurs (highgrowth, innovative or productive entrepreneurs), innovative, highly qualified employees, as well as different levels of government (Mason \& Brown, 2014; Stam, 2017; Stam \& Spigel, 2016). The major dimensions have been structured into framework conditions, macro-economic conditions and region-specific conditions, suggesting the breadth of the phenomenon under study (Stam, 2017; Stam \& Spigel, 2016). The analysis needs to cover both business-level factors, region-specific, socio-cultural factors, including human and social capital factors, and institutional arrangements among local, regional, and central governments (Brown \& Mason, 2017; Acs et al., 2017). Moreover, the links with external, international environment need to be considered as the expansion of high-growers and unicorns cannot be encapsulated within one territorial unit (Acs et al., 2017).

Particular locations or regions demonstrate unique elements and governance mechanisms, therefore, "one size fits all" solutions do not apply for the purpose of research and policy (Mason \& Brown, 2014; Brown \& Mason, 2017; Capozza et al., 2018). It is instrumental to identify some alternative models or frameworks that reflect the variety of territorial EEs, instead of promoting one universal model for all locations (Baker \& 
Powell, 2019; Hermann, 2019). The alternative models might serve as canvas to understand the nature and implications of a particular EE and to address it with tailored policy measures (Colombelli \& Paolucci, 2019).

The EE concept builds on and subsumes the earlier concepts of regional environment (Stam, 2017; Mason \& Brown, 2014; Isenberg, 2010). The theorists of EEs emphasize strong linkages between this concept and the earlier conceptualisations of the entrepreneurial context, such as clusters, industrial districts, and regional innovation systems (Stam, 2017; Mason \& Brown, 2014; Isenberg, 2010). The EE concept adds to these accomplishments and differentiates from them by focusing on the entrepreneur as the outcome and major driver of the EE governance and dynamics (Acs et al., 2017; Fernández-Serrano, Martínez-Román, \& Romero, 2018; Isenberg, 2010).

Brown and Mason (2017) synthesize and delimit the concept of EEs taking the spatial agglomeration phenomenon and industrial district literature as a starting point. The extant models of regional innovation networks point not only to actors and factors, but also to their causal logics (Markusen, 1996; Guerrieri \& Pietrobelli, 2004; Sturgeon, 2002). Markusen (1996) followed by Guerrieri and Pietrobelli (2004), as well as Sturgeon (2003) adopt an industrial district and governance perspective on the regional environment. However, the industrial perspective is not limited to one industry only, but it is rather a nexus of related industries resembling a regional specialised diversification or smart specialisation (Markusen, 1996; Foray, 2013; 2014; 2017). Industrial districts represent "sticky places" that make it difficult for smaller firms to leave, encouraging them to stay and expand, and attracting newcomers into the region (Markusen, 1996). They can be perceived as regional ecosystems comprising actors, with the leading role of firms interacting with human resources, local and central government, and resources, such as knowledge and technical support, as well as financing.

We derive the EE profiles from Markusen's typology (1996), combined with later insights from Guerrieri and Pietrobelli (2004) and Sturgeon (2002) that put stress on the role of industry technological advancement and on the importance of EEs' insertion into global value chains (Sturgeon, 2002). Following these insights, EEs can be categorised into four types, ${ }^{1}$ namely SME-dominated ecosystems, large and small firms' ecosystems, external investment-based ecosystems, and government-backed ecosystems (Markusen, 1996; Guerrieri \& Pietrobelli; Sturgeon, 2002). Each of these frameworks differentiates by structural features in the area of dominant firms (size, location of ownership and investment decisions), types of relationships (the strength duration of contracts) and collaboration culture, level of qualifications and mobility of personnel among firms, type of competitive strategy, stabilising mechanisms of sharing risk and innovation, as well as the role of local and central government. The breadth of actors and factors largely covers the dimensions of EE concepts (Mason \& Brown, 2014; Brown \& Mason, 2017; Spigel, 2017; Stam, 2017). Each type differs in implications for firms' performance and growth, as well as the sustainability of enterprises and the entire regional ecosystem. They are networked governance systems centred around and driven by the type of firms, particularly their size and ownership.

An SME-dominated regional EE is based on the population of small and medium-sized enterprises (SMEs) with local owners and thus investment decisions determined locally

\footnotetext{
${ }^{1}$ The original types of regional environments in Markusen's (1996) work were called "Marshallian," "Italianate," "hub and spokes," "satellite," and "state-anchored" districts.
} 
(Pahnke \& Welter, 2019). The strong and long-term cooperation among SMEs as well as the culture of mutuality and trust, generate stabilising mechanisms of sharing risk and innovation within joint projects (Litzel, 2017; Schröder, 2013; Malizia \& Motoyama, 2019). SME networks generate positive scale and scope economies, and knowledge externalities (Grillitsch \& Nilsson, 2019; Saxenian, 2000). The sources of financing and technical advice are accessible as business support institutions, e.g. business incubators, technology parks, seed funds, venture capitalist (Cumming, Werth, \& Zhang, 2019;). High qualifications of human resources and their mobility among firms enable knowledge spillovers and creativity (Bhawe \& Zahra, 2019; Hodges \& Link, 2019; Lehmann, Schenkenhofer, \& Wirsching, 2019). Consequently, the basis for competitive advantage are differentiation and product innovations rather than scale economies (Hodges \& Link, 2019; Schröder, 2013). The role of local and regional governments is more important than the role of central government. This type of regional governance is considered as providing good prospects for stable and profitable growth of firms and the entire territorial unit. It is based on strong local entrepreneurship, innovation, and investment decisions made by local owners (Markusen, 1996; Malizia \& Motoyama, 2019). However, the SME-based ecosystem has limited access to international markets and technologies, due to insufficient capacity of SMEs to organise foreign expansion (Gancarczyk \& Gancarczyk, 2018; Felzenstein et al., 2015; Francioni, Musso, \& Vardiabasis, 2013; Guerrieri \& Pietrobelli, 2004; Brown \& Mawson, 2016). Moreover, the growth of small firms is random and featured by discontinuity relative to the growth of large firms. The latter expand in a more persistent and predictable way, thus stabilising the regional economy (Brown \& Mason, 2017; Coad, 2009). Considering the lack of complementarity between small and large firms and a limited international reach of this ecosystem (Hermann, 2019), we formulate the following proposition.

Proposition 2.1: SME-dominated regional EEs are associated with moderate rates of enterprise growth and profitability relative to other types of EEs.

This type of EE can be more open to the international environment if the regional industrial base represents higher levels of technology advancement and R\&D intensity, as well as technological and market newness (Sussan \& Acs, 2017; Boix \& Trullén, 2007; Agostino et al., 2015; Aslesen \& Harirchi, 2015; Massini, Perm-Ajchariyawong, \& Lewin, 2010; Cusmano, Mancusi, \& Morrison, 2011; Kuratko et al., 2017). Moreover, regional knowledge transfer institutions, such as universities, can play a vital role in opening an EE to global value chains (Cunningham, Menter, \& Wirsching, 2019; Ghio, Guerini, \& Rossi-Lamastra, 2019; Meoli, Paleari, \& Vismara, 2019; Miller \& Acs, 2017; Duschl et al., 2014; 2015; Głodek, 2018). Proposition 2.2. assumes moderating roles of technology advancement and knowledge transfer institutions in SME-dominated EEs.

Proposition 2.2: The growth and performance of enterprises in an SME-dominated EE is strengthened provided that the industrial focus of this EE is high-technology and supported by knowledge-transfer institutions.

The large and small firms' ecosystems are centred around large enterprises (LEs) with headquarters located in the region where the major investment decisions are determined. LEs as focal firms and hubs pursue strong and long-term cooperation links with local SMEs, acting as sources of financing and technology transfer to regional enterprises (Giunta, Nifo, \& Scalera, 2012; Brown \& Mason, 2017; Pahnke \& Welter, 2019; Schröder, 2013). They are 
also a source of spin-offs, spin-outs, and business group affiliations that may strengthen the growth and performance of local enterprises (Sornn-Friese \& Sørensen, 2005; Klepper, 2006; Kalantaridis et al., 2012; Bamiatzi, 2014). These large "block-buster" or scale-up entrepreneurs bring knowledge spillovers by launching corporate accelerator programmes, by mentoring, board membership, and advisory (Colombo et al., 2019; Mason \& Brown, 2014). They also act as serial entrepreneurs, angel investors, and venture capitalists (Colombo et al., 2019; Malipiero, Munari, \& Sobrero, 2005; Munari, Sobrero \& Malipiero, 2011). Thus LEs substitute for external business support institutions and collaborative initiatives among small firms, typical of SME-dominated EEs (Koch \& Strotmann, 2006). Moreover, LEs form strong relationships with the cross-regional and international environment, being global pipelines and gate-openers to foreign markets and sources of technology for local entrepreneurs (Brown \& Mason, 2017; Schröder, 2013; Broome, Moore, \& Alleyne, 2018; Gilbert, McDougall, \& Audretsch, 2008). In this ecosystem, there is a larger fraction of human resources with lower qualifications to perform standardised manufacturing tasks. The preference for working conditions in LEs lowers the personnel mobility between SMEs and large enterprises (Markusen, 1996). The basis for competitive advantage are scale economies and process innovations as required by the strategies of LEs. Central government becomes a key partner to LEs, diminishing the role of regional government (Gereffi \& Lee, 2016). The large and small firms' ecosystem ensures stability and efficiency for local entrepreneurship and the entire territorial unit. This premise is based on the strength of focal firms. These are embedded in the region but with international sourcing opportunities that might turn to so called "genetic" proximity to other growing business environments (Colombo et al., 2019; Chaudry \& Ikram, 2015; Rice et al., 2012; Munari, Sobrero, \& Malipiero, 2011). The collaboration culture of this EE is hierarchical due to subcontracting, dependent position of SMEs (Gancarczyk \& Gancarczyk, 2016). This might lower their profitability, however, the advantage of market channels and knowledge spillovers from LEs outweigh these limitations (Brown \& Mawson, 2016; Brown \& Mason, 2017; Grillitsch \& Nilsson, 2019). Moreover, LEs demonstrate more predictable and persistent growth than small firms, thus stabilising the regional economy and acting as the source of growth of SMEs subcontractors (Brown \& Mason, 2017; Coad, 2009). Therefore, we formulate Proposition 3.1.

Proposition 3.1: Large and small firms' regional EEs are associated with higher rates of enterprise growth and profitability relative to other types of EEs.

The positive evaluation of this ecosystem may be weakened if we consider a moderating role of technology. In a lower-technology EE, the infusion of knowledge to small firms is limited and cost pressures are strong, due to more standardised activities outsourced by LEs (Stevenson, Kuratko, \& Eutsler, 2019; Robson \& Obeng, 2008). This observation leads us to Proposition 3.2.

Proposition 3.2: The growth and performance of enterprises in a large and small firms' EE is weakened if the industrial profile of this EE demonstrates lower technology.

An external investment ecosystem depends on large subsidiaries of transnational corporations (TNCS) with headquarters, major investment decisions, and sources of finance and technology out of the region (Markusen, 1996; Guerrieri \& Pietrobelli, 2004; Sturgeon, 
2002). Local SME population is weak, featuring limited and short-term business collaboration, financing or knowledge transfer from TNC subsidiaries (Ernst, 2004; Pavlínek, 2012, Rugraf, 2010; Pisoni et al., 2013; Filippov \& Duysters, 2011). The latter form strong linkages with corporate headquarters and other subsidiaries out of the region. The collaborative culture is weak and SMEs have minor opportunities for absorbing knowledge and finance through transacting with subsidiaries (Gauselmann, Knell, \& Stephan, 2011). Moreover, external financing and technical support are limited for SMEs and they feature hierarchical relations with TNC branches that impose cost cuts and lower margins (Biggiero, 2006). Regional SMEs do not establish joint initiatives to share risk and innovation through business associations or chambers of commerce. Subsidiaries compete on scale economies with limited commitment to innovative activities except for non-technological innovations (Gauselmann, Knell, \& Stephan, 2011; De Marchi, Giuliani, \& Rabellotti, 2017). The FDIbased regional economy is unstable, due to volatility of TNCs' investment that can easily move to more attractive regions. Moreover, the excessive focus of the regional economy on the TNC's specialisation crowds out innovations and firms in other areas (Pathak, Laplum, \& Xavier Oliveira, 2015; Brown \& Mason, 2017; Mason \& Brown, 2013; Feeny, lamsiraroj, \& McGillivray, 2014). Therefore, the characteristics of external investment ecosystems are in general less favourable for stability and profitability of regional entrepreneurship.

Proposition 4.1: External investment regional EEs are associated with lower rates of enterprise growth and profitability relative to other types of EEs.

The impact of these ecosystems is moderated by the level of technology dominating in the region (Duschl et al., 2014; 2015; Cusmano, Mancusi, \& Morrison, 2010; Agostino, 2015; Boix \& Trullén, 2007). Knowledge-intensive and high-technology regional specialisations, as well as embedded relationships with the TNC branches can result in upgrading, growth and enhanced performance of local firms (Gorynia et al., 2007; Larimo \& Arslan, 2013; Ivarsson \& Alvstam, 2011; Lee \& Saxenian, 2008; Kodama \& Shibata, 2013; Simms \& Trott, 2014; Yan, Chiang, \& Chien, 2014). Higher technology manufacturing and service sector FDI might foster the growth and performance of local firms (Hart \& McGuinness, 2003; Gancarczyk, Gancarczyk, \& Bohatkiewicz, 2017).

Moreover, embedding subsidiaries by the regional government can enable local enterprises to reap benefits from FDI (Dziemianowicz, Łukomska, \& Ambroziak, 2018). The establishment of collaborations and technology transfer depends also on absorptive capacity, such as human resource qualifications and capabilities of regional enterprises (Bhawe \& Zahra, 2019; Fernández-Serrano, Martínez-Román, \& Romero, 2018, Gancarczyk \& Bohatkiewicz, 2018).

Proposition 4.2: The growth and performance of enterprises in an external investment regional $\mathrm{EE}$ are strengthened if the industrial focus of this $E E$ is high-technology, regional absorptive capacity is high, and regional government is active in embedding subsidiaries.

A government-backed regional $E E$ is built on publicly-owned institutions or firms that establish predominantly short-term and weak collaborations with local entrepreneurs (Markusen, 1996). Therefore, the enterprise population is rather modest and passive in creating joint stabilising instruments within business associations (Sternberg \& Wennekers, 2005). This ecosystem suffers from the shortages of external finance and knowledge sources 
that impede the growth of firms (Donati \& Sarno, 2015). Lower-skilled labour demonstrates a weak capacity to absorb and benefit from public funding in the area of R\&D (Tingvall \& Videnord, 2018). Economies of scale in the public sector dominate as a method to compete. The government-backed ecosystems are dependent on the investment decisions of central government, which follows political cycles and budget constraints (Humphrey et al., 2018). This prevents the stability of local entrepreneurship and the entire territorial unit.

Proposition 5.1: Government-backed regional EEs are associated with lower rates of enterprise growth and profitability relative to other types of EEs.

The type of innovative output in a government-backed EE depends on the type of major entities, i.e. whether they are "large and small firms" or "SME-dominated," or they are branches of government institutions that are headquartered out of the region ("external investment" ecosystem) (Arauzo-Carod, Segarra-Blasco, \& Teruel, 2018). The preferred EE profile would be based on the complementarity of LEs such as large, government-owned institutions or enterprises, and SMEs. Larger entities collaborating with SMEs might be helpful in implementing regional innovation policy and specialisation (Foray, 2014; Gancarczyk \& Bohatkiewicz, 2018), and in integrating the regional EE with global value chains (Pietrobelli \& Rabellotti, 2011; Gereffi \& Lee, 2016; Lema, Rabellotti, \& Sampath, 2018; European Commission, 2016).

An alternative advantageous profile would be formed by a vibrant SME community, such as the one centred around a technology park (Markusen, 1996; Pletrobelli \& Rabellotti, 2011; Arauzo-Carod, Segarra-Blasco, \& Teruel, 2018). In this case, central and regional government policies may be conducive to the occurrence of firms' growth and the type of growth (Jankowska, Gotz, \& Głowka, 2017; Corrente et al., 2019). The examples are taxation and SME support policies that often raise the preference for business group formation instead of scaling up an individual company (lacobucci, 2002). As a consequence, the SME-dominated structures emerge.

Proposition 5.2: The growth and performance of enterprises in the government-backed regional EE is strengthened if it assumes the large and small firms' or SME-dominated characteristics.

\section{The Framework}

The synthesis of the above literature review is a framework that explores the relationships between the performance of high-growth enterprises and the characteristics of regional entrepreneurial ecosystems.

The logics of this framework is based on the premise that EEs are heterogeneous and we need to capture this variety as alternative profiles rather than as one model only. CEEs can be categorised into types according to a set of structural characteristics, and then quantitatively investigated with the use of taxonomical approaches. These characteristics include the dominant entities in the $\mathrm{EE}$, their ownership, as well as the level and type of relationships and collaboration culture, type of competitive advantage and innovation, human resource qualifications, the sources of external financing and technical advice, as well as the role of regional and central government. Propositions 1, 2, 3, 4, and 5 express the 
impact of regional context on the growth and performance of enterprises. Figure 1 presents how particular EE profiles affect the growth and performance of enterprises, indicating possible dynamics due to moderating factors.

The structural characteristics of regional EES

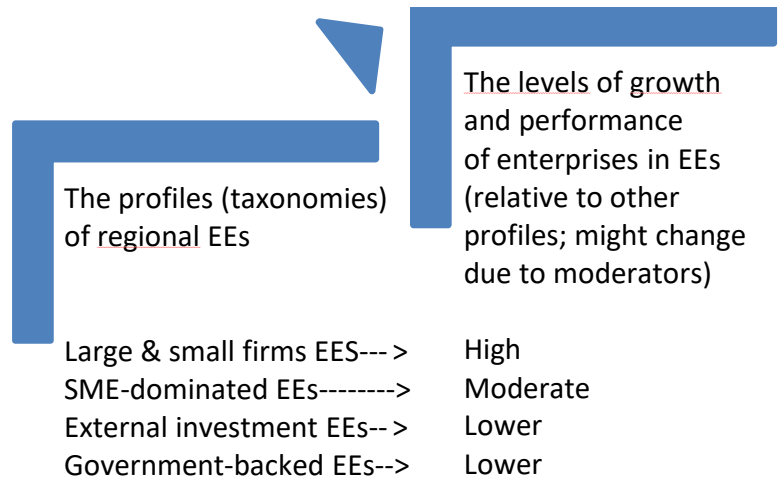

Figure 1. The framework of relationships between the performance of high-growth enterprises and the characteristics of regional entrepreneurial ecosystems Source: own elaboration.

The prospective empirical research based on this framework would involve three phases as depicted in Figure 1. In the first phase, the structural characteristics of regional EEs need to be described. In the second phase, the profiles or taxonomies of regional EEs are identified. In the third phase, five hypotheses can be tested as to how particular profiles of EEs affect the growth and performance of enterprises. The research can confirm extant hypotheses and thus maintain the proposed typology, or it can reject or modify the profiles derived from the theory. The same refers to growth and performance implications of specific ecosystem types.

\section{DISCUSSION}

This study has integrated the research streams of firm growth and entrepreneurial ecosystems and thus it offers the following contributions.

(i) It advances the literature on entrepreneurial ecosystems, by proposing how different profiles of EEs contribute to firms' growth and performance.

The study responds to the heterogeneous nature of regional environments by offering the profiling approach rather than one ideal model of the entrepreneurial ecosystem (Acs et al., 2017; Simsek et al., 2017; Law et al., 1998). By capturing a variety of possible solutions, we avoid the "one-size fits all" approach (Mason \& Brown, 2013; Martin \& Sunley, 2003; Capozza et al., 2018). In our propositions, we point to a number of variants that are different but some of them are also alternative and equifinal if moderators are considered. As recommended by EE researchers (Brown \& Mason, 2017; Acs et al., 2017; Stam, 2017), we drew upon extant models of spatial agglomeration, particularly, industrial district and cluster literature, to ensure knowledge accumulation regarding regional 
environment (Markusen, 1996; Sturgeon, 2003; Guerrieri \& Pietrobelli, 2004). The input from this study consists in refreshing these models based on later developments in entrepreneurship and regional studies, and in focusing them on the issue of enterprise growth and performance. Although the idea of Markusen's (1996) regional governance types was earlier adopted by Brown \& Mason (2017), we have deepened and nuanced their findings. Brown \& Mason come up with only two profiles of EEs, which raises doubts whether it can be claimed a taxonomical approach that captures a variety of existing EE types. Their framework is parsimonious in identifying only embryonic (far from ideal) EEs and scale up (ideal) EEs, and thus giving a clear directions for benchmarking and improvements. On the other hand, it leaves a number of other variants unaddressed. The embryonic-scale up opposition ranges from an extremely limited number of high-quality locations that generate unicorns and global high-growers, to lowquality and underdeveloped territories. The framework proposed in this research may be treated as complementary and more nuanced approach to better capture idiosyncrasy as well as substitutability of EE resources and institutions.

Moreover, we address the current criticisms of the EE concept, such as static approach, insufficient recognition of the governance mechanisms and relationships among actors and factors, as well as input instead of output orientation in the evaluation of EEs. The extant models emphasize the components and dimensions of EEs, however, they rarely point to causal relations that would be centred around enterprises and business relationships (Stam \& Spigel, 2016; Colombo et al., 2019; Audretsch \& Link, 2019; Colombelli \& Paolucci, 2019). We propose testing the profiles of EEs - causal relations among actors and factors rather than sets of isolated determinants. The alternative profiles suggest the dynamism and evolutionary considerations, namely, transformation of the extant EE profiles to more developed ones (Guerrieri \& Pietrobelli, 2004; Pietrobelli \& Rabellotti, 2011; Lee \& Saxenian, 2007). Moreover, we clearly emphasize the outcomes of EEs in terms of productive entrepreneurship, by underlining the importance of studying not only size increases (growth), but also the performance of high-growers (Davidsson et al., 2009; Steffen et al., 2009; Nicotra et al., 2019).

(ii) This article advances the studies in the entrepreneurial growth, by proposing how the performance of high-growers is conditioned by the context.

In the studies on firm growth, the issues of performance are underexplored and current results are inconclusive regarding the relationships between expansion as size increase and performance as economic efficiency (Davidsson, Steffen, \& Fitzsimmons, 2009; Steffen, Davidsson, \& Fitzsimmons, 2009). The article proposes that this inconsistency is resolved by the inclusion of regional environment as a moderator of this relationship (Kangasharju, 2000; Lumpkin \& Dess, 1996; Corrente et al., 2019). We also identify how particular regional ecosystems might influence the performance of high-growers.

(iii) Finally, the proposed research framework integrates firm growth and EE studies thus enabling knowledge accumulation (Isenberg, 2010; Stam, 2017).

This integrative study enabled to formulate the advanced research problem that addresses the gaps in both study areas. We responded to this problem by acknowledging the findings and achievements of these areas, with results mutually benefitting them, as stated in points (i) and (ii) above. This enhances the upgraded theory and joint efforts 
of research communities that have acted separately to date. It can also lead to more informed and comprehensive results for public policy and business practice.

\section{CONCLUSIONS}

This research has accomplished the aim to develop a framework exploring the relationships between the characteristics of entrepreneurial ecosystems and the performance of high-growth enterprises. The propositions address the research problem of how different profiles of EEs affect firms' growth and profitability. Our framework brings the implications for further research, as well as for entrepreneurial practice and policy.

First, the framework raises direct implications for further conceptual and empirical studies. This framework was accomplished with the use of a conceptual approach and based on the review of literature in the area of entrepreneurship and regional development. Due to the emerging and underexplored nature as well as integrative and broad topics, narrative review was determined as the major method (Collins \& Fauser, 2005). Narrative review by nature involves subjectivity of literature choices, use of heuristics and stylised approach to a larger extent than systematic literature review does (Green et al., 2006). This weakens the article's argument. Systematic search was added as a complementary method, however, we cannot claim the overall systematic approach.

The arguments in favour of combining narrative and systematic literature reviews are the quality of results and the validity of findings. Complementing the narrative review with the systematic review supports the article's contribution. The propositions and the resulting framework would be less valid, if not backed by broader evidence (Leavitt et al., 2010). Moreover, combining narrative and systematic reviews is recommended to alleviate the weaknesses of each method (Hoon, 2013). The subjectivity of narrative reviews can be alleviated by systematic reviews. On the other hand, systematic reviews, although more objective than narrative ones, might still be inaccurate due to incomplete databases and technical errors. Thus, manual search and narrative reviews help to resolve this bias.

This study forms a ground for further conceptual and theoretical papers that would focus on specific questions and tackle them with systematic literature reviews (Green et al., 2006; Hoon, 2013). Possible themes include policy interventions in ecosystems, evolution and upgrading of EEs, or in-depth exploration of individual dimensions of EEs, such as the collaboration patterns, leading actors, and EEs in global value chains.

Our propositions as to the impact of various EEs on firms' growth and performance were not directly derived from the models used as canvas in this study. They were formulated based on the inference from the findings of regional development and entrepreneurship studies that explored similar actors and factors. This indirect inference limits the validity of the causal relations proposed and calls for verification in empirical research (Hoon, 2013). Upon our framework and propositions, testable hypothesis can be developed to either confirm or verify the proposed causal relations and their moderators.

When formulating propositions, this research focused on identifying the major constructs rather than specific variables and their measurement. The latter should be the task for future research, when propositions need to be converted into testable hypotheses, i.e., the assumptions as to relationships among measurable variables. However, the operationalisation of the research framework and the development of testable hypotheses will be 
a challenging task, and it needs to be acknowledged as a limitation of our research results. This is due to the complexity and multiple dimensions of EEs that need to be decomposed for the purpose of operationalisation (Stam, 2015). Moreover, the variety of growth measures and the role of time in measuring growth-profitability interdependencies still remain unresolved in research on firm expansion. When reviewing the literature, we found similar difficulties as already identified in the literature, namely a variety of measures applied in the sample of the reviewed papers (Achtenhagen, Naldi, \& Melin, 2010). The sampled studies rarely reported the time lag effect between growth and profitability (Wiklund, 1999; Garnsey et al., 2006; Steffens et al., 2009; Glancey, 1998; Bolek, 2018). Considering a broad array of dimensions and constructs describing the profiles of EEs, it would not be possible to identify any patterns of growth measures relating to the EE profiles or dimensions. This aspect calls for future studies that would acknowledge the importance of expansion measures and the role of time in studying enterprise growth in regional contexts.

The findings of this article demonstrate also implications for entrepreneurial practice and policies. Entrepreneurs can recognize the influence of contextual factors on their prospects for growth and profitability, and thus understand opportunities and threats from the regional environment (Chandler, McKelvie, \& Davidsson, 2009; Wach, 2008; Lisowska, 2012; Welter, 2011). Policy-makers are encouraged to consider EEs' implications for regional entrepreneurship and to plan measures tailored to their territorial units in promoting productive entrepreneurship (Stam \& Spigel, 2016). Thinking in terms of alternative solutions and equifinality is stimulated this way (Baker \& Powell, 2019). Moreover, the implications for policy-makers include the evolution and transformation of their territorial units towards more advanced, scale up EEs (Guerrieri \& Pietrobelli, 2004; Pietrobelli \& Rabellotti, 2011; Colombo et al., 2019). When looking for stimulants that might drive this evolution, they can consider moderators suggested in the propositions, such as embedding FDIs, input from scientific institutions, building on the industrial base of knowledgeintensive and high-technology industries, and type of public entities established in lagged regions to foster their entrepreneurial performance.

\section{REFERENCES}

Achtenhagen, L., Naldi, L., \& Melin, L. (2010). Business growth-do practitioners and scholars really talk about the same thing? Entrepreneurship Theory and Practice, 34(2), 289-316.

Acs, Z.J., Stam, E., Audretsch, D.B., \& O'Connor, A. (2017). The lineages of the entrepreneurial ecosystem approach. Small Business Economics, 49(1), 1-10.

Acs, Z., Parsons, W., \& Tracy, S. (2008). High-impact firms: Gazelles revisited. U.S. Small Business Administration: Washington DC.

Agostino, M., Giunta, A., Nugent, J.B., Scalera, D., \& Trivieri, F. (2015). The importance of being a capable supplier: Italian industrial firms in global value chains. International Small Business Journal, 33(7), 708-730. https://doi.org/10.1177\%2F0266242613518358

Antony, J., Klarl, T., \& Lehmann, E.E. (2017). Productive and harmful entrepreneurship in a knowledge economy. Small Business Economics, 49(1), 189-202.

Arauzo-Carod, J., Segarra-Blasco, A., \& Teruel, M. (2018). The role of science and technology parks as firm growth boosters: An empirical analysis in Catalonia. Regional Studies, 52(5), 645-658. https://doi.org/10.1080/00343404.2018.1447098 
Aslesen, H.W., \& Harirchi, G. (2015). The effect of local and global linkages on the innovativeness in ICT SMEs: does location-specific context matter? Entrepreneurship \& Regional Development, 27(9-10), 644-669. https://doi.org/10.1080/08985626.2015.1059897

Audretsch, D.B., \& Link, A.N. (2019). Embracing an entrepreneurial ecosystem: an analysis of the governance of research joint ventures. Small Business Economics, 52(2), 429-436.

Auerswald, P.E. (2015). Enabling entrepreneurial ecosystems: Insights from ecology to inform effective entrepreneurship policy. Kansas City: Kauffman Foundation.

Auerswald, P.E., \& Dani, L. (2017). The adaptive life cycle of entrepreneurial ecosystems: the biotechnology cluster. Small Business Economics, 49(1), 97-117.

Baker, T., \& Powell, E.E. (2019). Entrepreneurship as a new liberal art. Small Business Economics, 52(2), 405-418.

Bamiatzi, V., Cavusgil, S.T., Jabbour, L., \& Sinkovics, R.R. (2014). Does business group affiliation help firms achieve superior performance during industrial downturns? An empirical examination. International Business Review, 23(1), 195-211. https://doi.org/10.1016/j.ibusrev.2013.04.003

Barbosa, N., \& Eiriz, V. (2011b). Regional Variation of Firm Size and Growth: The Portuguese Case. Growth and Change, 42(2), 125-158. https://doi.org/10.1111/j.1468-2257.2011.00547.x

Bau, M., Chirico, F., Pittino, D., Backman, M., \& Klaesson, J. (2019). Roots to Grow: Family Firms and Local Embeddedness in Rural and Urban Contexts. Entrepreneurship Theory and Practice, 43(2), 360-385. https://doi.org/10.1177/1042258718796089

Baughn, C.C., Sugheir, J., \& Neupert, K.E. (2010). Labor flexibility and the prevalence of high-growth entrepreneurial Activity1. Journal of Small Business and Entrepreneurship, 23(1), 1-15, 153-154.

Baumol, W.J. (1996). Entrepreneurship: Productive, unproductive, and destructive. Journal of Business Venturing, 11(1), 3-22.

Bellandi, M. (2001). Local development and embedded large firms. Entrepreneurship \& Regional Development, 13(3), 189-210. https://doi.org/10.1080/08985620110051103

Bhawe, N., \& Zahra, S.A. (2019). Inducing heterogeneity in local entrepreneurial ecosystems: the role of MNEs. Small Business Economics, 52(2), 437-454.

Biggiero, L. (2006). Industrial and knowledge relocation strategies under the challenges of globalization and digitalization: the move of small and medium enterprises among territorial systems. Entrepreneurship \& Regional Development, 18(6), 443-472. https://doi.org/10.1080/08985620600884701

Birch, D., Haggerty, A., \& Parsons, W. (1995). Who's creating Jobs? Cambridge, MA: Cognetics.

Bolek, M. (2018). Determinanty wzrostu przedsiębiorstw na rynku kapitałowym. Łódź: Wydawnictwo Uniwersytetu Łódzkiego.

Bottazzi, G., \& Secchi, A. (2006). Explaining the distribution of firm growth rates. The RAND Journal of Economics, 37(2), 235-256.

Broome, T., Moore, W., \& Alleyne, P. (2018). Financing constraints and the R\&D decision in the Caribbean. Entrepreneurship and Regional Development, 30(9-10), 964-986. https://doi.org/10.1080/08985626.2018.1515820

Brown, R., \& Mason, C. (2017). Looking inside the spiky bits: a critical review and conceptualisation of entrepreneurial ecosystems. Small Business Economics, 49(1), 11-30.

Brown, R., \& Mawson, S. (2016). The geography of job creation in high growth firms: The implications of 'growing abroad'. Environment and Planning C: Government and Policy, 34(2), 207-227. doi:10.1177/0263774X15614152 
Brown, R., Mawson, S., \& Mason, C. (2017). Myth-busting and entrepreneurship policy: the case of high growth firms. Entrepreneurship \& Regional Development. https://doi.org/10.1080/08985626.2017.1291762.

Bruns, K., Bosma, N., Sanders, M., \& Schramm, M. (2017). Searching for the existence of entrepreneurial ecosystems: a regional cross-section growth regression approach. Small Business Economics, 49(1), 31-54.

Capozza, C., Salomone, S., \& Somma, E. (2018). Local industrial structure, agglomeration economies and the creation of innovative start-ups: evidence from the Italian case. Entrepreneurship \& Regional Development, 30(7-8), 749-775.

Chandler, G., McKelvie A., \& Davidsson, P. (2009). Asset specificity and behavioral uncertainty as moderators of the sales growth - employment growth relationship in emerging ventures. Journal of Business Venturing, 24(4), 373-387

Chaudhry, A., \& Ikram, R. (2015). Does genetic proximity to high growth countries affect a country's own growth? Economic Modelling, 51, 444-453. https://doi.org.10.1016/j.econmod.2015.08.031

Coad, A. (2009). The growth of firms: A survey of theories and empirical evidence. Cheltenham: Edward Elgar Publishing.

Collins, J.A., \& Fauser, B.C. (2005). Balancing the strengths of systematic and narrative reviews. Human Reproduction Update, 11(2), 103-104. https://doi.org/10.1093/humupd/dmh058

Colombelli, A., Paolucci, E., \& Ughetto, E. (2019). Hierarchical and relational governance and the life cycle of entrepreneurial ecosystems. Small Business Economics, 52(2), 505-521.

Colombo, M.G., \& Grilli, L. (2005). Founders' human capital and the growth of new technology-based firms: A competence-based view. Research Policy, 34(6), 795-816.

Colombo, M.G., Dagnino, G.B., Lehmann, E.E., \& Salmador, M. (2019). The governance of entrepreneurial ecosystems. Small Business Economics, 52(2), 419-428.

Corrente, S., Greco, S., Nicotra, M., Romano, M., \& Schillaci, C.E. (2019b). Evaluating and comparing entrepreneurial ecosystems using SMAA and SMAA-S. Journal of Technology Transfer, 44(2), 485-519. https://10.1007/s10961-018-9684-2

Cumming, D., Werth, J.C., \& Zhang, Y. (2019). Governance in entrepreneurial ecosystems: venture capitalists vs. technology parks. Small Business Economics, 52(2), 455-484.

Cusmano, L., Mancusi, M.L., \& Morrison, A. (2010). Globalization of production and innovation: how outsourcing is reshaping an advanced manufacturing area. Regional Studies, 44(3), 235-252. https://doi.org/10.1080/00343400802360451

Davidsson, P., Steffens, P.R., \& Fitzsimmons, J.R. (2009). Growing profitable or growing from profits: putting the horse in front of the cart?. Journal of Business Venturing, 24(4), 388-406.

de Guevara, J.F., \& Maudos, J. (2009). Regional financial development and bank competition: Effects on firms' growth. Regional Studies, 43(2), 211-228. https://doi.org/10.1080/00343400701808907

De Marchi, V., Giuliani, E., \& Rabellotti, R. (2018). Do Global Value Chains offer developing countries learning and innovation opportunities? The European Journal of Development Research, 30(3), 389-407.

Dierickx, I., \& Cool, K. (1989). Asset stock accumulation and sustainability of competitive advantage. Management Science, 35(12), 1504-1511. Retrieved from eprints.qut.edu.au/archive/00012040/

Dominiak, P., Wasilczuk, J., \& Starnawska, M. (2016). Przedsiębiorczość nieproduktywna w świetle ekonomii instytucjonalnej. Analiza zjawiska w Polsce. Warszawa: Wydawnictwo Naukowe PWN.

Donati, C., \& Sarno, D. (2015). Are firms in "backward" areas of developed regions more financially constrained? The case of Italian SMEs. Industrial and Corporate Change, 24(6), 1353-1375. https://doi.org/10.1093/icc/dtu030 
Duschl, M., Schimke, A., Brenner, T., \& Luxen, D. (2014). Firm Growth and the Spatial Impact of Geolocated External Factors. Jahrbucher Fur Nationalokonomie Und Statistik, 234(2-3), 234-256.

Duschl, M., Scholl, T., Brenner, T., Luxen, D., \& Raschke, F. (2015). Industry-specific firm growth and agglomeration. Regional Studies, 49(11), 1822-1839. https://doi.org/10.1080/00343404.2013.861059

Dziemianowicz, W., Łukomska, J., \& Ambroziak, A.A. (2018). Location factors in foreign direct investment at the local level: the case of Poland. Regional Studies, 1-10.

Eliasson, K., Hansson, P., \& Lindvert, M. (2017). Effects of foreign acquisitions on R\&D and high-skill activities. Small Business Economics, 49(1), 163-187.

Ernst, D. (2004). How sustainable are benefits from global production networks? Malaysia's upgrading prospects in the electronics industry. In J. Kidd \& F-J. Richter (2004), Trust and Antitrust in Asian Business Alliances (pp 209-230). London: Palgrave Macmillan.

European Commission. (2016). Smart guide to cluster policy. Guidebook Series: How to support SME Policy through Structural Funds. Brussels: European Commission.

Fang, J.G., \& Guo, H.W. (2013b). Electronic information industry, clustering and growth: empirical study of the Chinese enterprises. Chinese Management Studies, 7(2), 172-193. https://doi.org/10.1108/CMS-Sep-2011-0083

Feeny, S., lamsiraroj, S., \& McGillivray, M. (2014). Growth and foreign direct investment in the Pacific Island countries. Economic Modelling, 37, 332-339. https://doi.org/10.1016/j.econmod.2013.11.018

Felzensztein, C., Ciravegna, L., Robson, P., \& Amorós, J.E. (2015). Networks, entrepreneurial orientation, and internationalization scope: evidence from Chilean small and medium enterprises. Journal of Small Business Management, 53(1), 145-160. https://doi.org/10.1111/jsbm.12188

Fernández-Serrano, J., Martínez-Román, J.A., \& Romero, I. (2018). The entrepreneur in the regional innovation system. A comparative study for high-and low-income regions. Entrepreneurship \& Regional Development, 1-20.

Filippov, S., \& Duysters, G. (2011). Competence-building in foreign subsidiaries: The case of new EU member states. Journal for East European Management Studies, 16(4), 286-314.

Foray, D. (2013). The economic fundamentals of smart specialisation. Ekonomiaz, 83(2), 83-102.4

Foray, D. (2014). Smart specialisation: Opportunities and challenges for regional innovation policy. Abington, New York: Routledge.

Foray, D. (2017). The economic fundamentals of smart specialization strategies. In S. Radosevic, A. Curaj, R. Gheorghiu, L. Andreescu, \& I. Wade (Eds.), Advances in the Theory and Practice of Smart Specialization. Academic Press, 38-50.

Francioni, B., Musso, F., \& Vardiabasis, D. (2013). Key decisions and changes in internationalization strategies: the case of smaller firms. Journal of Strategic Marketing, 21(3), 240-25. https://doi.org/10.1080/0965254X.2013.790466

Gagliardi, F. (2009). Financial development and the growth of cooperative firms. Small Business Economics, 32(4), 439-464. https://doi.org/10.1007/s11187-007-9080-z

Gancarczyk, M., \& Bohatkiewicz, J. (2018). Research streams in cluster upgrading: a literature review. Journal of Entrepreneurship, Management and Innovation, 14(4), 17-42.

Gancarczyk, M., \& Gancarczyk, J. (2016). SME supplier upgrading during the cooperation life cycleEvidence from Central and Eastern Europe. Journal of East European Management Studies, 21(3), 318-351.

Gancarczyk, M., \& Gancarczyk, J. (2018). Proactive international strategies of cluster SMEs. European Management Journal, 36(1), 59-70.

Gancarczyk, M., Gancarczyk, J., \& Bohatkiewicz, J. (2017). SME roles in modular value chains: Perspectives for growth and innovativeness. Entrepreneurial Business and Economics Review, 5(3), 95-117. 
Garnsey, E., Stam, E., \& Heffernan, P. (2006). New firm growth: Exploring processes and paths. Industry and Innovation, 13(1), 1-20.

Gauselmann, A., Knell, M., \& Stephan, J. (2011b). What drives FDI in Central-Eastern Europe? Evidence from the IWH-FDI-Micro database. Post-Communist Economies, 23(3), 343-357. https://doi.org/10.1080/14631377.2011.595148

Gereffi, G., \& Lee, J. (2016). Economic and social upgrading in global value chains and industrial clusters: Why governance matters. Journal of Business Ethics, 133(1), 25-38.

German Cooperation. (2018). Guide for Mapping the Entrepreneurial Ecosystem: Observe - Analyse - Visualise. Frankfurt: Deutsche Gesellschaft für Internationale Zusammenarbeit (GIZ) GmbH.

Ghio, N., Guerini, M., \& Rossi-Lamastra, C. (2019). The creation of high-tech ventures in entrepreneurial ecosystems: exploring the interactions among university knowledge, cooperative banks, and individual attitudes. Small Business Economics, 52(2), 523-543.

Gilbert, B.A., McDougall, P.P., \& Audretsch, D.B. (2008). Clusters, knowledge spillovers and new venture performance: An empirical examination. Journal of Business Venturing, 23(4), 405-422. https://doi.org/10.1016/j.jbusvent.2007.04.003

Giunta, A., Nifo, A., \& Scalera, D. (2012). Subcontracting in Italian industry: Labour division, firm growth and the north-south divide. Regional Studies, 46(8), 1067-1083. https://doi.org/10.1080/00343404.2011.552492

Glancey, K. (1998). Determinants of growth and profitability in small entrepreneurial firms. International Journal of Entrepreneurial Behaviour \& Research, 4(1), 18-27.

Głodek, P. (2018). Akademicki spin-off. Wiedza, zasoby i ścieżki rozwoju. Łódź: Wydawnictwo Uniwersytetu Łódzkiego.

Gorynia, M., Nowak, J., Howak, J., \& Wolniak, R. (2007). Motives and modes of FDI in Poland: An exploratory qualitative study. Journal for East European Management Studies, 132-151.

Green, B.N., Johnson, C.D., \& Adams, A. (2006). Writing narrative literature reviews for peer-reviewed journals: Secrets of the trade. Journal of Chiropractic Medicine, 5(3), 101-117. https://doi.org/10.1016/S0899-3467(07)60142-6

Grillitsch, M., \& Nilsson, M. (2019). Knowledge externalities and firm heterogeneity: Effects on high and low growth firms. Papers in Regional Science, 98(1), 93-114. https://doi.org/10.1111/pirs.12342

Guerrieri, P., \& Pietrobelli, C. (2004). Industrial districts' evolution and technological regimes: Italy and Taiwan. Technovation, 24(11), 899-914.

Hambrick, D.C., \& Crozier, L.M. (1985). Stumblers and stars in the management of rapid growth. Journal of Business Venturing, 1(1), 31-45.

Hart, M., \& McGuinness, S. (2003). Small firm growth in the UK regions 1994-1997: Towards an explanatory framework. Regional Studies, 37(2), 109-122. https://doi.org/10.1080/0034340022000057523

Herrmann, A.M. (2019). A plea for varieties of entrepreneurship. Small Business Economics, 52(2), 331-343.

Hodges, N.J., \& Link, A.N. (2019). Innovation by design. Small Business Economics, 52(2), 395-403.

Hoon, C. (2013). Meta-synthesis of qualitative case studies: An approach to theory building. Organizational Research Methods, 16(4), 522-556. https://doi.org/10.1177\%2F1094428113484969

Humphrey, J., Ding, K., Fujita, M., Hioki, S., \& Kimura, K. (2018). Platforms, innovation and capability development in the Chinese domestic market. The European Journal of Development Research, 30(3), 408-423. 
lacobucci, D. (2002). Explaining business groups started by habitual entrepreneurs in the italian manufacturing sector. Entrepreneurship and Regional Development, 14(1), 31-47. https://doi.org/10.1080/08985620110096636

Isenberg, D.J. (2010). How to start an entrepreneurial revolution. Harvard Business Review, 88(6), 40-50.

Isenberg, D., \& Brown, R. (2014). For a booming economy, bet on high-growth firms, Not Small Businesses. Babson Entrepreneurship Ecosystem Project. Retrieved from http://blogs.hbr.org/2014/02/for-a-booming-economy-beton-high-growth-firms-not-small-businesses/ on June 28, 2019.

Ivarsson, I., \& Alvstam, C.G. (2010). Upgrading in global value-chains: a case study of technologylearning among IKEA-suppliers in China and Southeast Asia. Journal of Economic Geography, 11(4), 731-752. https://doi.org/10.1093/jeg/lbq009

Jankowska, B., Gotz, M., \& Głowka, C. (2017). Intra-cluster cooperation enhancing SMEs' competitiveness - the role of cluster organisations in Poland. [La cooperación intraclúster mejora la competitividad de las PYME: El papel de las organizaciones de clusters en Polonia] Investigaciones Regionales, 39, 195-214.

Janssen, F. (2009). Does the environment influence the employment growth of SMEs? Journal of Small Business and Entrepreneurship, 22(3), 311-325,377.

Jayawarna, D., Jones, O., \& Macpherson, A. (2011a). New business creation and regional development: Enhancing resource acquisition in areas of social deprivation. Entrepreneurship and Regional Development, 23(9-10), 735-761. https://doi.org/10.1080/08985626.2010.520337

Kalantaridis, C., Vassilev, I., \& Fallon, G. (2011). Enterprise strategies, governance structure and performance: A comparative study of global integration. Regional Studies, 45(2), 153-166. https:/doi.org/10.1080/00343400903365136

Kangasharju, A. (2000). Growth of the smallest: Determinants of small firm growth during strong macroeconomic fluctuations. International Small Business Journal, 19(1), 28-43.

Karlsson, C., \& Dahlberg, R. (2003b). Entrepreneurship, firm growth and regional development in the new economic geography: Introduction. Small Business Economics, 21(2), 73-76. https://doi.org/10.1023/a:1025036125745

Kim, Y.J., \& Lee, C.I. (2019). Sovereign Debt Crisis in a Monetary Union: Accounting for Excessive Debt, Housing Bubbles, and the Transmission of Crises. Economic Inquiry, 57(2), 1098-1119. https://doi.org/10.1111/ecin.12745

Klepper, S. (2007). Disagreements, spinoffs, and the evolution of Detroit as the capital of the U.S. automobile industry. Management Science, 53(4), 616-631. https://doi.org/10.1287/mnsc.1060.0683

Koch, A., \& Strotmann, H. (2006b). Impact of functional integration and spatial proximity on the postentry performance of knowledge intensive business service firms. International Small Business Journal, 24(6), 610-634. https://doi.org/10.1177/0266242606069269

Kuratko, D.F., Fisher, G., Bloodgood, J.M., \& Hornsby, J.S. (2017). The paradox of new venture legitimation within an entrepreneurial ecosystem. Small Business Economics, 49(1), 119-140.

Larimo, J., \& Arslan, A. (2013). Determinants of foreign direct investment ownership mode choice: Evidence from Nordic investments in Central and Eastern Europe. Journal for East European Management Studies, 18(2), 232-263.

Law, K.S., Wong, C.S., \& Mobley, W.M. (1998). Toward a taxonomy of multidimensional constructs. Academy of Management Review, 23(4), 741-755. https://doi.org/10.5465/amr.1998.1255636 
Leavitt, K., Mitchell, T.R., \& Peterson, J. (2010). Theory pruning: Strategies to reduce our dense theoretical landscape. Organizational Research Methods, 13(4), 644-667. https://doi.org/10.1177\%2F1094428109345156

Lee, C.K., \& Saxenian, A. (2007). Coevolution and coordination: a systemic analysis of the Taiwanese information technology industry. Journal of Economic Geography, 8(2), 157-180. https://doi.org/10.1093/jeg/lbm049

Lehmann, E.E., Schenkenhofer, J., \& Wirsching, K. (2019). Hidden champions and unicorns: A question of the context of human capital investment. Small Business Economics, 52(2), 359-374. https://doi.org/10.1007/s11187-018-0096-3

Lema, R., Rabellotti, R., \& Sampath, P.G. (2018). Innovation trajectories in developing countries: Coevolution of Global Value Chains and innovation systems. The European Journal of Development Research, 30(3), 345-363.

Lipińska, A. (2018). Koncepcje i kluczowe czynniki rozwoju ekosystemów startupów. Studia Ekonomiczne, 351, 46-57.

Lisowska, R. (2015). External determinants of the development of small and medium-sized enterprises - empirical analysis. Journal of Entrepreneurship, Management and Innovation, 11(4). https:// doi.org/ 10.7341/20151145

Litzel, N. (2017). Does embeddedness in clusters enhance firm survival and growth? an establishment-level analysis using CORIS data. Regional Studies, 51(4), 563-574. https://doi.org/ 10.1080/00343404.2015.1115009

Lumpkin, G.T., \& Dess, G.G. (1996). Clarifying the entrepreneurial orientation construct and linking it to performance. Academy of Management Review, 21(1), 135-172.

Malipiero, A., Munari, F., \& Sobrero, M. (2005). Focal firms as technological gatekeepers within industrial districts: knowledge creation and dissemination in the Italian packaging machinery industry. Copenhagen: DRUID working papers, Copenhagen Business School.

Malizia, E., \& Motoyama, Y. (2019). Vibrant Centers as Locations for High-Growth Firms: An Analysis of Thirty US Metropolitan Areas. Professional Geographer, 71(1), 15-28. https://doi.org/ 10.1080/00330124.2018.1501708

Markman, G.D., \& Gartner, W.B. (2002). Is extraordinary growth profitable? A study of Inc. 500 highgrowth companies. Entrepreneurship Theory and Practice, 27(1), 65-75.

Markusen, A. (1996). Sticky places in slippery space: a typology of industrial districts. Economic Geography, 72(3), 293-313.

Marris, R. (1964). The Economic Theory of "Managerial" Capitalism. London: Macmillan.

Mason, C., \& Brown, R. (2013). Creating good public policy to support high-growth firms. Small Business Economics, 40(2), 211-225. https://doi.org/10.1007/s11187-011-9369-9

Mason, C., \& Brown, R. (2014). Entrepreneurial ecosystems and growth oriented entrepreneurship. Final Report to OECD, Paris, 30(1), 77-102.

Massini, S., Perm-Ajchariyawong, N., \& Lewin, A.Y. (2010). Role of corporate-wide offshoring strategy on offshoring drivers, risks and performance. Industry and Innovation, 17(4), 337-371. https://doi.org/10.1080/13662716.2010.496242

Meoli, M., Paleari, S., \& Vismara, S. (2019). The governance of universities and the establishment of academic spin-offs. Small Business Economics, 52(2), 485-504.

Miller, D.J., \& Acs, Z.J. (2017). The campus as entrepreneurial ecosystem: the University of Chicago. Small Business Economics, 49(1), 75-95.

Mogos, S., Davis, A., \& Baptista, R. (2015). Defining high growth firms: sustainable growth, volatility, and survival. DRUID 15, Rome, June 15, 17.

Nicholls-Nixon, C.L. (2005). Rapid growth and high performance: The entrepreneur's "impossible dream?". Academy of Management Perspectives, 19(1), 77-89. 
Nicotra, M., Romano, M., Del Giudice, M., \& Schillaci, C.E. (2018). The causal relation between entrepreneurial ecosystem and productive entrepreneurship: a measurement framework. Journal of Technology Transfer, 43(3), 640-673. https://doi.org/10.1007/s10961-017-9628-2

OECD. (2010). High-growth enterprises: What governments can do to make a difference. OECD Publishing.

OECD-Eurostat, E.O. (2007). Manual on business demography statistics. OECD Publishing.

Oliveira, B., \& Fortunato, A. (2006). Firm growth and liquidity constraints: A dynamic analysis. Small Business Economics, 27(2-3), 139-156.

Pahnke, A., \& Welter, F. (2019). The German Mittelstand: antithesis to Silicon Valley entrepreneurship?. Small Business Economics, 52(2), 345-358.

Pathak, S., Laplume, A., \& Xavier-Oliveira, E. (2015). Inbound foreign direct investment and domestic entrepreneurial activity. Entrepreneurship \& Regional Development, 27(5-6), 334-356.

Pavlínek, P. (2012). The internationalization of corporate R\&D and the automotive industry R\&D of East-Central Europe. Economic Geography, 88(3), 279-310.

Pietrobelli, C., \& Rabellotti, R. (2011). Global value chains meet innovation systems: are there learning opportunities for developing countries? World Development, 39(7), 1261-1269. https://doi.org/10.1016/j.worlddev.2010.05.013

Pisoni, A., Fratocchi, L., \& Onetti, A. (2013). Subsidiary autonomy in transition economies: Italian SMEs in Central and Eastern European countries. Journal for East European Management Studies, 18(3), 336-370. https://doi.org/10.5771/0949-6181-2013-3-336

Rice, M.D., Tierney, S., O'Hagan, S., Lyons, D., \& Green, M.B. (2012). Knowledge, influence, and firmlevel change: A geographic analysis of board membership associated with Canada's growing and declining businesses. Geoforum, 43(5), 959-968. doi:10.1016/j.geoforum.2012.04.005

Robson, P.J.A., \& Obeng, B.A. (2008). The barriers to growth in Ghana. Small Business Economics, 30(4), 385-403. https://doi.org/10.1007/s11187-007-9046-1

Rugraff, E. (2010). Foreign direct investment (FDI) and supplier-oriented upgrading in the Czech motor vehicle industry. Regional Studies, 44(5), 627-638. https://doi.org/10.1080/00343400903095253

Saxenian, A. (2000). Regional networks in Silicon Valley and Route 128. In Z.J. Acs, Regional innovation, knowledge, and global change (pp 123-138). London: Pinter.

Schröder, C. (2013). Regional and company-specific factors for high growth dynamics of ICT companies in Germany with particular emphasis on knowledge spillovers. Papers in Regional Science, 92(4), 741-772. https://doi.org/10.1111/j.1435-5957.2012.00457.x

Shane, S. (2009). Why encouraging more people to become entrepreneurs is bad public policy. Small Business Economics, 33(2), 141-149. https://doi.org/10.1007/s11187-009-9215-5

Shepherd, D., \& Wiklund, J. (2009). Are we comparing apples with apples or apples with oranges? Appropriateness of knowledge accumulation across growth studies. Entrepreneurship Theory and Practice, 33(1), 105-123. https://doi.org/10.1111\%2Fj.1540-6520.2008.00282.x

Simsek, Z., Heavey, C., \& Fox, B.C. (2017). (Meta-) framing strategic entrepreneurship. Strategic Organization, 15(4), 504-518. https://doi.org/10.1177\%2F1476127017711720

Sornn-Friese, H., \& Sørensen, J.S. (2005). Linkage lock-in and regional economic development: the case of $\varnothing$ resund medi-tech plastics industry. Entrepreneurship \& Regional Development, 17(4), 267-292. https://doi.org/10.1080/08985620500218695

Spigel, B. (2017). The Relational Organization of Entrepreneurial Ecosystems. Entrepreneurship Theory and Practice, 41(1), 49-72. https://doi:10.1111/etap.12167

Stam, E. (2015). Entrepreneurial ecosystems and regional policy: a sympathetic critique. European Planning Studies, 23(9), 1759-1769.

Stam, E., Suddle, K., Hessels, J., \& Van Stel, A. (2009). High-growth entrepreneurs, public policies, and economic growth. In Baptista R \& Leitao, J. (Eds.), Public policies for fostering entrepreneurship. New York: Springer, 91-110.

Stam, F.C., \& Spigel, B. (2016). Entrepreneurial ecosystems. USE Discussion Paper Series, 16(13). 
Stangler, D., \& Bell-Masterson, J. (2015). Measuring an entrepreneurial ecosystem. Kauffman Foundation Research Series on City, Metro, and Regional Entrepreneurship, 16.

Steffens, P., Davidsson, P., \& Fitzsimmons, J. (2009). Performance configurations over time: implications for growth-and profit-oriented strategies. Entrepreneurship Theory and Practice, 33(1), 125-148.

Sternberg, R., \& Wennekers, S. (2005b). Determinants and effects of new business creation using Global Entrepreneurship Monitor data. Small Business Economics, 24(3), 193-203. https://doi.org/10.1007/s11187-005-1974-z

Stevenson, R.M., Kuratko, D.F., \& Eutsler, J. (2019). Unleashing main street entrepreneurship: Crowdfunding, venture capital, and the democratization of new venture investments. Small Business Economics, 52(2), 375-393.

Sturgeon, T.J. (2002). Modular production networks: a new American model of industrial organisation. Industrial and Corporate Change, 11(3), 451-496.

Sussan, F., \& Acs, Z.J. (2017). The digital entrepreneurial ecosystem. Small Business Economics, 49(1), 55-73.

Thomas, L.D., Sharapov, D., \& Autio, E. (2018). Linking entrepreneurial and innovation ecosystems: The case of AppCampus. In Carayannis, E.G, Dagnino, G.B., Alvarez, S., \& Faraci, R. (Eds.), Entrepreneurial Ecosystems and the Diffusion of Startups. Cheltenham: Edward Elgar Publishing.

Tingvall, P.G., \& Videnord, J. (2018). Regional differences in effects of publicly sponsored R\&D grants on SME performance. Small Business Economics, https://doi.org/10.1007/s11187-018-0085-6

Wach, K. (2008). Identyfikacja i strukturalizacja cech otoczenia przedsiębiorstwa. Organizacja i Kierowanie, 1, 57-72.

Wach, K. (2012). Europeizacja małych i średnich przedsiębiorstw: rozwój przez umiędzynarodowienie. Warszawa: Wydawnictwo Naukowe PWN.

Welter, F. (2011). Contextualizing entrepreneurship-conceptual challenges and ways forward. Entrepreneurship Theory and Practice, 35(1), 165-184.

Welter, F., Baker, T., \& Wirsching, K. (2019). Three waves and counting: the rising tide of contextualization in entrepreneurship research. Small Business Economics, 52(2), 319-330.

Wiklund, J. (1999). The sustainability of the entrepreneurial orientation-performance relationship. Entrepreneurship Theory and Practice, 24(1), 37-48.

Wiklund, J., \& Shepherd, D. (2003). Aspiring for, and achieving growth: The moderating role of resources and opportunities. The Journal of Management Studies, 40(8), 1919-1941.

Wiklund, J., Patzelt, H., \& Shepherd, D.A. (2009). Building an integrative model of small business growth. Small Business Economics, 32(4), 351-374.

Yan, H.D., Chiang, C., \& Chien, C.S. (2014). From original equipment manufacturing to branding: entrepreneurship, strategic leadership, and Taiwan's firm transformation. International Entrepreneurship and Management Journal, 10(1), 81-102.

Zahra, S.A. (2007). Contextualizing theory building in entrepreneurship research. Journal of Business Venturing, 22(3), 443-452.

Zahra, S.A., \& Wright, M. (2011). Entrepreneurship's next act. Academy of Management Perspectives, 25(4), 67-83.

Zahra, S.A., Wright, M., \& Abdelgawad, S.G. (2014). Contextualization and the advancement of entrepreneurship research. International Small Business Journal, 32(5), 479-500. https://doi.org/10.1177\%2F0266242613519807

Zbierowski, P. (2012). Orientacja pozytywna organizacji wysokiej efektywności. Warszawa: Wolters Kluwer. 


\section{Author}

\section{Marta Gancarczyk}

Associate Professor (dr hab.) at the Institute of Economics, Finance and Management, Jagiellonian University in Cracow, Poland; Head of the Department of Globalization and Economic Integration. Her research, publication and consulting activities focus on entrepreneurship, firm growth, technology management and commercialisation, industrial clusters and public policy for small and medium-sized enterprises. She is Associate Editor of the international scientific journal "Journal of Entrepreneurship, Management and Innovation" and Member of the Editorial Advisory Board of the "Journal of Organizational Change Management."

Correspondence to: Dr. Hab. Marta Gancarczyk, prof. UJ, Institute of Economics, Finance and Management, Jagiellonian University in Krakow, ul. prof. S. Lojasiewicza 4, 30-348 Krakow, Poland, e-mail: marta.gancarczyk@uj.edu.pl

ORCID 구 http://orcid.org/0000-0003-2078-9320

\section{Acknowledgements and Financial Disclosure}

The research presented in this article is based on the funds from Polish Ministry of Science and Higher Education supporting statutory activities of the Faculty of Management and Social Communication, Jagiellonian University, Krakow, Poland. The draft version of the paper was presented at the conference "Entrepreneurship in Modern Economy" (ENTIME), April 11-12, 2019, Gdansk Technical University. The author would like to thank the anonymous referees indicated by EBER for their useful comments, which allowed to increase the value of this article.

\section{Copyright and License}

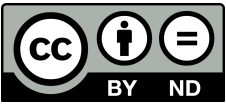

This article is published under the terms of the Creative Commons Attribution - NoDerivs (CC BY-ND 4.0) License http://creativecommons.org/licenses/by-nd/4.0/

\section{Published by the Centre for Strategic and International Entrepreneurship - Krakow, Poland}

The copyediting and proofreading of articles in English is financed in the framework 
